\title{
PEMBERDAYAAN MASYARAKAT MELALUI INOVASI PRODUK UNTUK MENINGKATKAN PEREKONOMIAN DI DESA LENGKONG KECAMATAN GARAWANGI KABUPATEN KUNINGAN JAWA BARAT
}

\author{
Wely Hadi Gunawan*, Neng Evi Kartika \\ Universitas Kuningan, Indonesia \\ *welyhadigunawan@uniku.ac.id
}

\begin{abstract}
Utilization of village potential is an effort made by the government to improve the welfare of the village community itself. But because of the lack of community creativity in terms of food packaging, lack of knowledge in developing existing products, and lack of knowledge in terms of food marketing so as to cause limited community knowledge in managing the potential of the existing village, this is a major factor in the hampering of the progress of the village. Lengkong Village Garawangi District Kuningan regency is a producer of special food one of them reginang made from dried glutinous rice. There are also various chips, but the raw materials obtained come from other villages. Please note msme village Lengkong Garawangi subdistrict is quite good. On this occasion community service was carried out seminars and training in order to be able to innovate products, held seminars and training to take care of PIRT, and seminars and digital marketing training.
\end{abstract}

Keywords: diversification strategy, smes, msmes, community empowerment, community development, strategy management

\begin{abstract}
Abstrak
Pemanfaatan potensi desa merupakan upaya yang senatiasa dilakukan pemerintah untuk meningkatkan kesejahteraan masyarakat desa itu sendiri. Namun karena kurangnya kreativitas masyarakat dalam hal pengemasan makanan, kurangnya pengetahuan dalam mengembangkan produk yang ada, dan kurangnya pengetahuandalam hal pemasaran makanan sehingga menyebabkan keterbatasan pengetahuan masyarakat dalam mengelola potensi desa yang ada ini menjadikan faktor utama terhambatnya kemajuan dari desa tersebut. Desa Lengkong Kecamatan Garawangi Kabupaten Kuningan merupakan penghasil makanan khas salah satunya reginang yang terbuat dari beras ketan yang dikeringkan. Ada juga aneka kripik, namum bahan baku yang didapat berasal dari desa lain. Perlu diketahui UMKM desa Lengkong Kecamatan Garawangi cukup baik. Pada kesempatan ini pengabdian masyarakat yang dilaksanakan seminar dan pelatihan agar mampu melakukan inovasi produk, diadakan seminar dan pelatihan mengurus PIRT, dan seminar dan pelatihan digital marketing

Kata Kunci: strategi diversifikasi, ukm, umkm, pemberdayaan masyarakat, community development, manajemen strategi
\end{abstract}

\begin{tabular}{l|l|l} 
Submitted: $2021-08-16$ & Revised: $2021-10-07$ & Accepted: 2021-10-26
\end{tabular}

\section{Pendahuluan}

UKM memiliki peran penting dalam membantu dan memberikan kontribusi terhadap perekonomian Indonesia. Hal paling sederhana, dengan adanya UKM dapat mengurangi tingkat pengangguran minimal diwilayah domisili UKM itu berada. Walaupun UKM sangat berperan bagi perekonomian, namun pada kenyataannya memiliki daya saing yangmasih rendah. Hal ini disebabkan karena berbagai keterbatasan, mulai dari sumber daya manusia yang kurang kreatif dalam berinovasi, kurang jeli dalam melihat peluang yang ada, serta kurangnya modal membuat mereka enggan berkembang untuk mencari pasar baru.

Kabupaten Kuningan merupakan salah satu wilayah yang berada di Provinsi Jawa Barat yang posisinya tepat berada di kaki Gunung Ciremai. Dengan letak ini, Kabupaten Kuningan memiliki berbagai potensi mulai dari sumber daya alam, sumber daya manusia, sumber sejarah, dan letak geografisnya. Memiliki wilayah pemerintahan 32 kecamatan, 361 desa dan 15 kelurahan, memberikan banyak peluang untuk dapat meningkatkan pertumbuhan UKM sesuai dengan sebaran 
wilayah yang luas. Berdasarkan data Dinas Koperasi dan UKM tahun 2015 terdapat jumlah UMKM sebanyak 21.334 yang terdiri dari UMKM pertanian 13.204 unit, industri perdagangan 3.376 unit, Industri non perdagangan 1.232 unit dan jasa lain 3.522 unit.

Legalitas merupakan salah satu syarat penting dalam menjalankan sebuah usaha, dimana produk yang dikeluarkan untuk didistribusikan kepada kondumen sudah memiliki izin edar. Legalitas ini bisa diberikan untuk jenis usaha produk jasa ataupun produk berupa barang. Jenis Perizinan usaha yang digunakan oleh UMKM sendiri dibagi menjadi 2 kelompok antara lain Perizinan Badan Usaha/Akta Pendirian Usaha (CV, PT, Koperasi), Surat Keterangan Domisisli Usaha (SKDU), Nomor Pokok Wajib Pajak (NPWP). Selain itu, untuk jenis perizinan usaha Dagang seperti Produk Industri Rumah Tangga (P-IRT), Badan Pengawas Obat dan Makanan (BPOM), Hinder Ordonantie (HO), Halal-MUI dan lain sebagainya.

Pentingnya perizinan bagi UMKM akan memberikan sebuah kepercayaan konsumen dan membantu dalam keberlangsungan hidup produk di masyarakat. Sebagaian besar UMKM masih menganggap untuk mendapatkan perizinan usaha sulit diperoleh. Berdasarkan jumlah UMKM yang ada di Kabupaten Kuningan sebanyak 21.334 UMKM, telah mempekerjakan sebanyak 37.506 pegawai, dengan jumlah aset operasional yang dihasilkan sebesar Rp1.098.165.064.900 dengan total keuntungan Rp. 611.617.663.200. Adapun UMKM terbanyak ada di Kecamatan Cibingbin mencapai 375. Menyusul 277 UMKM di Kecamatan Kadugede dan 270 UMKM di Kecamatan Cimahi. Kecamatan Kuningan sendiri hanya 108 UMKM. Dari 21.334 UMKM di Kuningan, baru 5.151 UMKM yang telah mendapat binaan pemkab. Artinya 5.151 tersebut telah mendapat fasilitasi bantuan, baik berupa pelatihan, peralatan, mesin termasuk legalitas formal PIRT dan lain-lain. Jumlah tersebut masih sangat sedikit dibanding potensi yang ada. Hal ini karena terbatasnya dana yang dimiliki oleh pemerintah dan juga kesiapan dari UMKM itu sendiri.

Pada umumnya permasalahan yang dihadapi UMKM adalah permodalan yang terbatas bersumber dari pemilik usaha. Namun, disisi lain permasalahan yang dihadapi dan cukup penting lainnya yaitu daya saing dan pemasaran produk. Hal ini dikarenakan akses jaringan UMKM yang terbatas mengakibatkan perluasan usaha dan kemampuan penetrasi pasar masih rendah, sehingga pertumbuhan UMKM masih belum signifikan. Kelemahan UMKM yang terjadi dikarenakan masih menggunakan metode organik (tradisional), keterbatasan SDM dari segi pendidikan, pengetahuan dan keterampilannya sangat berpengaruh terhadap manajemen pengelolaan usahanya dan kurangnya informasi teknologi serta aplikasi digitalisasi usaha bagi UMKM masih belum optimal.

Desa Lengkong merupakan salah satu Desa yang berada di Kecamatan Garawangi Kabupaten Kuningan Provinsi Jawa Barat, yang dijadikan sebagai lokasi penelitian untuk Pengabdian Masyarakat. Berdasarkan analisis situasi yang telah dipaparkan, permasalahan yang terjadi pada UMKM di Desa Lengkong yaitu kurangnya pengelolaan dalam hal Manajemen Pemasaran baik itu dari sisi packaging, labeling dan branding juga dari kelengkapan legalitas usaha yang harus dipenuhi oleh UMKM. Hal ini diindikasikan sebagai penyebab kurangnya daya saing untuk menarik konsumen membeli produk lokal hasil dari UMKM Desa Lengkong.

Atas dasar latar belakang diatas, peneliti menganalisa bahwa perlu adanya peningkatan kapasitas UMKM mulai dari sosialisasi, pelatihan, pendampingan dan pengembangan usaha untuk bisa meningkatkan UMKM strat up menjadi UMKMscale up yang memiliki daya saing baik di nasional maupun internasional. Sehingga, proses bisnis UMKM akan berkembang dan memberikan dampak positif kepada peningkatan pendanpatan UMKM dan juga masyarakat di sekitar Desa Lengkong. 


\section{Metode}

Metode pelakasanaan merupakan landasan atau acuan agar proses dalam program pengabdian kepada masyarakat ini berjalan secara sistematis, terstruktur, dan terarah setelah proses observasi lapangandan identifikasi permasalahan dilakukan, maka akan dilakukan perancangan solusi. Selanjutnya solusi yang telah dilakasanakanakan ditawarkan kepada mitra UMKM. Alur kegiatan pengabdian masyarakat di Desa Lengkong Kecamatan Garawangi Kabupaten KuninganJawa Barat ditunjukan pada gambar 1.

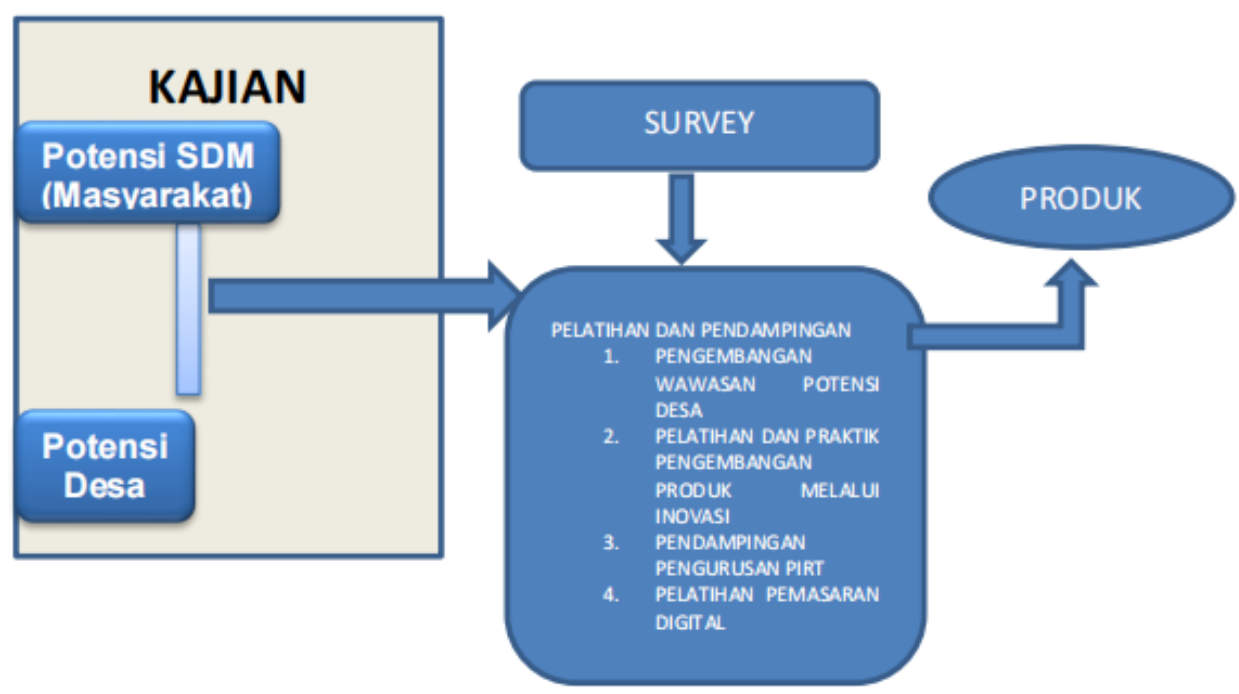

Gambar 1. Alur kegiatan pengabdian masyarakat

Berdasarkan permasalahan yang sudah diidentifikasi dan dirumuskan diatas maka metode pelaksanaan kegiatan yang digunakan dalam pengabdian ini menggunakan metode antara lain :

1. Sosialisasi dan pelatihan merupakan proses belajar mengajar dengan menggunakan teknik dan metode tertentu secara konsepsional dengan tujuan untuk meningkatkan keterampilan dan kemampuan seseorang atau sekelompok orang (Siagian dalam Lubis, 2008). Adapun teknik yang digunakan dalam metod epelatihan antara lain Teknik presentasi (ceramah dan diskusi) dan Praktik Inovasi.

2. Pendampingan dilakukan denganp endekatan individual dan klasikal. Pendekatan klasikal dilakukan pada saat pemberian teori dalam melakukan pembukuan sederhana dan pengelolaan keuangan.

Adapun langkah - langkah pelaksanaan kegiatan dalam pemberdayaan UMKM dan pendampingan dalam melakukan inovasi secara intensif melalui: (1) Seminar dan workshop mengenaiperan home industry membangun ekonomi desa; (2) Pelatihan dan praktik inovasi pada produk home industry; (3) Pelatihan pemasaran digital; dan (4) Evaluasi.

Pemantauan pelaksanaan pengabdian kepada masyarakat dilaksanakan setiap satu minggu sekali selama 2 minggu setelah pelatihan dan pendampingan. Adapun beberapa dokumentasi dalam kegiatan pelaksanaan pemberdayaan masyarakat kepada pelaku/mitra UMKM di Desa Lengkong sebagai berikut: 


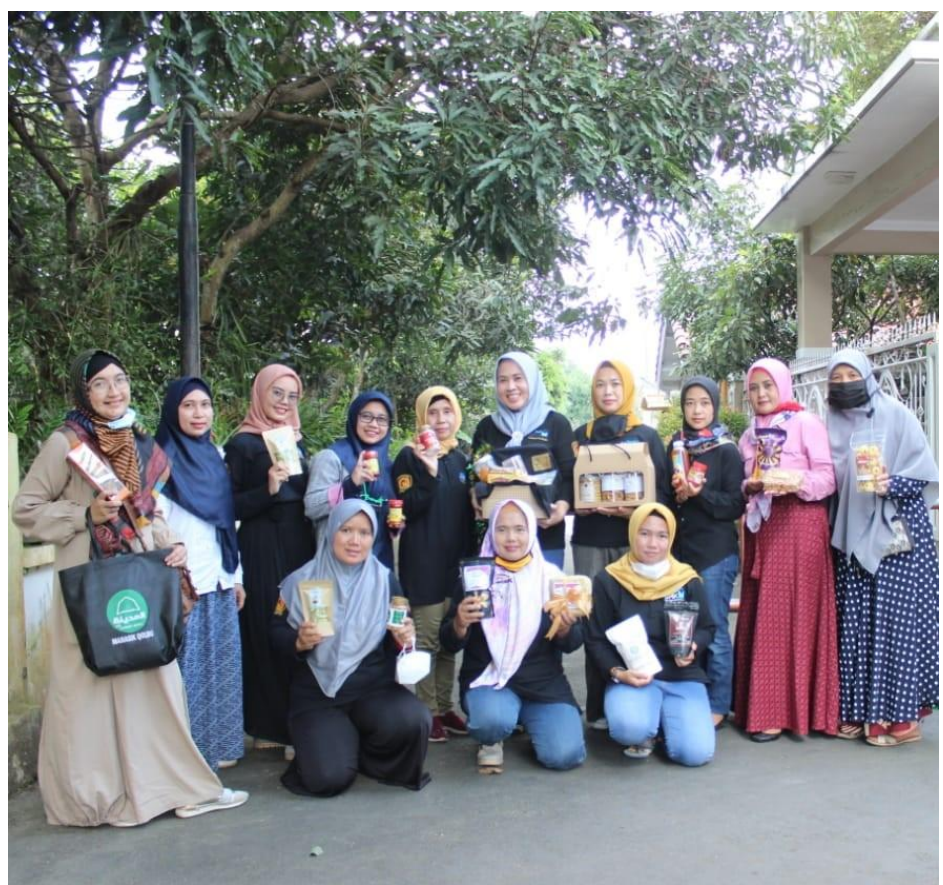

Gambar 2. Pelatihan dan Inovasi Kemasan

\section{Hasil dan Pembahasan}

Kegiatan PKM dilaksanakan pada tanggal 16-18 November 2020dengan bentuk pelatihan danpendampingan Pemberdayaan Masyarakat Berbasis Potensi Desa melalui Inovasi Pada Desa LengkongKecamatan Garawangi Kabupaten Kuningan Jawa Barat kepada pelaku bisnis UMKM terutama ibu - ibu PKK Desa Lengkong Kecamatan Garawangi Kabupaten Kuningan Jawa Barat diharapkan dapat meningkatkan taraf hidup mereka dengan melakukan inovasi produk yang mereka miliki. Inovasi yang disarankan untuk peningkatan nilai produk yaitu merubah packaging / kemasan produk supaya lebih menarik dan disesuaikan dengan kebutuhan produk yang diciptakan, kemudian tidak lupa memberikan pelabelan pada produk sehingga memberikan ciri khas untuk produk yang dibuat menjadi dikenal dan terakhir melakukan branding melalui aktivitas pemasaran seperti melakukan event gelar produk dan memberikan produk sample kepada masyarakat dalam satu event tertentu. Selain itu, penerapan dalam memanfaatkan penggunaan teknologi (gadget) sebagai media promosi produk untuk mengakses ke pasar lebih luas. Tidak lupa dalam hal ini UMKM terus mendapatkan pembinaan dalam memperoleh izin PIRT yang memang membutuhkan waktu beberapa bulan lamanya.

Beberapa faktor pendukung dalam pelaksanaan pelatihan dan pendampingan yaitu peserta yang sangat antusias dalam mengikuti pelatihan dan pendampingan, dan dukungan dari aparatur pemerintah Desa Lengkong Kecamatan Garawangi Kabupaten Kuningan Jawa Barat.

\section{Kesimpulan}

PKM dengan tema Pemberdayaan Masyarakat Berbasis Potensi Desa melalui Inovasi Pada Desa Lengkong Kecamatan Garawangi Kabupaten Kuningan Jawa Barat, memiliki peluang besar untuk ditingkatkan ke arah scale up sehingga dapat segera memberikan kontribusi dalam peningkatan perekonomian khususnya bagi pelaku/mitra UMKM yang ada di Desa Lengkong dan umumnya kepeada masyarakat terutama terutama Kader PKK dalam pengembangan produk dan pemasaran melalui teknologi. 


\section{Daftar Pustaka}

RPJMDes Desa Tembong Kecamatan Garawangi Kabupaten Kuningan

RPJM Kabupaten Kuningan tahun 2018-2023

Undang-Undang Nomor 23 Tahun 2014 tentang Pemerintahan Daerah, sebagaimana telah diubah beberapa kali, terakhir dengan Undang-Undang Nomor 9 Tahun 2015.

Undang Undang Nomor 6 tahun 2014 tentang Desa 